Meta

Journal des traducteurs

Translators' Journal

\title{
On the Implausibility of Equivalent Response (Part I)
}

\section{Qian $\mathrm{Hu}$}

Volume 37, numéro 2, juin 1992

URI : https://id.erudit.org/iderudit/003148ar

DOI : https://doi.org/10.7202/003148ar

Aller au sommaire du numéro

Éditeur(s)

Les Presses de l'Université de Montréal

ISSN

0026-0452 (imprimé)

1492-1421 (numérique)

Découvrir la revue

Citer cet article

Hu, Q. (1992). On the Implausibility of Equivalent Response (Part I). Meta, 37(2), 289-301. https://doi.org/10.7202/003148ar

\section{Résumé de l'article}

Cet article étudie la théorie de l'équivalence dynamique de Nida afin de déterminer si elle peut constituer un but à atteindre dans la pratique de la traduction. On commence par un survol de divers concepts fondamentaux en linguistique puis on compare la théorie de Nida avec d'autres approches. On discute ensuite de la nature du langage et on se concentre sur la compréhension en tant que processus mental. 


\title{
ON THE IMPLAUSIBILITY OF EQUIVALENT RESPONSE (Part I)
}

QIAN Hu

Pacific Grove, California, USA

\begin{abstract}
Résumé
Cet article étudie la théorie de l'équivalence dynamique de Nida afin de déterminer si elle peut constituer un but à atteindre dans la pratique de la traduction. On commence par un survol de divers concepts fondamentaux en linguistique puis on compare la théorie de Nida avec d'autres approches. On discute ensuite de la nature du langage et on se concentre sur la compréhension en tant que processus mental.
\end{abstract}

\begin{abstract}
This paper sets out to investigate Eugene Nida's theory of equivalent response and to decide whether it is an achievable goal for practising translators. The exposition commences with a survey of various important concepts in the linguistic field. The theory of equivalent response is compared with other approaches to the problem of obtaining translations which are both readable and faithful to the original text.
\end{abstract}

The nature of language is discussed with reference to the similarities (shared characteristics) and dissimilarities (idiosyncratic features). It is asserted that language is a system of dialectical relationships which sustains translation and hinders equivalent effect at the same time.

Held in the light of transformational grammar, a discussion on Nida's three-stage procedure, a translating model designed for achieving dynamic equivalence, exposes the sterility of this procedure; as sentence meanings are not determined by the deep structure and they are distorted in transformations, dynamic equivalence is not guaranteed by following this roundabout procedure.

Attempts are also made to justify the philosophical assumption that content and form are inseparable. Based on this assumption is the deduction that meaning is untransferable; translation is only an act of substitution of a TL content-form entity for an SL content-form entity.

Understanding as a mental process is another major concern of this paper; attention is drawn to the active role of the receptor and the subjectivity of response understanding is an effort-involving act in which the receptor's personality, level of education, experience, cultural background and other relevant factors affect the way he interprets the perceived data.

The conflicting claims of form and content and the numerous factors influencing individual reactions to any text combine to convince the writer that equivalent response is an implausible theory, and unlikely to be a satisfactory guide to practical translation.

\section{INTRODUCTION}

The systematic study of translation began in the late eighteenth century. The publication of Alexander Fraser Tytler's book Essays on the Principles of Translation in 1790 proclaims that translation study as a science has come into existence in its own right 
(Amos 1920: 137). The nineteenth and twentieth centuries have seen a rapid development of the science with linguists, translators and writers engaged in the study of translation; a large contingent of translation students has been formed. Among them, one of the most outstanding is Dr. Eugene Nida, who is executive secretary for translations of the American Bible Society.

Dr. Nida approaches translation study in a communicative way, and on the basis of transformational grammar he works out a translation model, attempting to describe scientifically the process of transfer - importing meaning to one language from another. The core of his translation theory is equivalent response, a condition where the receptor language audience responds to the translation in the same or similar way as the source language audience responds to the original. In his model, he demonstrates how to achieve dynamic equivalence by back-transformation from surface structure to deep structure in the source language (SL) and forward-transformation from deep structure to surface structure in the target language (TL). He believes that dynamic equivalence will elicit equivalent response from the receptor audience. This theory is expounded in two of his principal works - Toward a Science of Translating (1964) and The Theory and Practice of Translation (1969, in collaboration with Charles Taber). His later works, with modifications and development, are based on these two works.

Nida's theory exerts a worldwide influence on translation study, moving it into a new stage (cf. Newmark 1981: 9). However, as no translation is final (Newmark 1981: 17), no translation theory is ever complete (cf. Amos 1920: xiii). Therefore whether Nida's theory is applicable to translation practice needs to be verified. Can the theoretical axis on which his model depends endure practical application? Can dynamic equivalence be achieved through transformation? Can dynamic equivalence, even if achievable, produce equivalent response as Nida's assumes?

In the hope that Nida's theory might be properly evaluated, this paper attempts to answer these questions concentrating on the analysis of his two major works (1964, 1969), with references where necessary to his other works. My main theme is that equivalent response is impossible, and attempts are made to justify this in various aspects. Chapter I discusses important concepts such as "equivalence," "equivalence types" and "equivalent response." References show the relationship of Nida's concepts to their predecessors, and comparisons are also made to provide a better understanding of Nida's concepts.

Chapter II attempts to justify the assumption that language is a system of dialectical relationships which sustains translation and renders impossible the equivalent effect of translation at the same time.

"A three-stage procedure," the translating model designed by Nida for achieving dynamic equivalence, is fully investigated in Chapter III. As the meaning of a sentence cannot be determined by its deep structure, and as transformations involve meaningchanging this procedure is found incapable of producing dynamic equivalence.

Chapter IV sets out to justify the philosophical assumption that content and form are inseparable. Based on this assumption is the deduction that meaning is untransferable; translation is only an act of substitution of a TL content-form entity for an SL contentform entity.

The major concern of the last chapter is understanding, which is an effort-taking act in which the decoder's personality, level of education, experience, cultural background and other relevant factors affect the way he interprets the perceived data. translation.

The conclusion summarises my evaluation of Nida's theory with reference to 


\section{CHAPTER I EQUIVALENT RESPONSE}

An attempt to deal with the problem of equivalence should be an integral part of every translation theory, for translating entails a comparison of the TL version with the original text. To study translating as a mental process, it is necessary to clarify the type of relationship which exists between the TL version and the original. Until this has been established, studies in translation can make little progress for it is this relationship which distinguishes translating from creative writing. Observations on this aspect of translation form the crux of translation theory and every adequate theory develops from a specific understanding of the balance between the original text and the TL version.

\section{EQUIVALENCE}

Since equivalence implies a comparability between two linguistic code-systems, it has long been "the cardinal problem of language and the pivotal concern of linguistics" (Jacobson 1959: 233). It is generally acknowledged that translation is a process that operates on compatibility as the axis between two linguistic code-systems, so it is no exaggeration to say that equivalence is also a "pivotal concern" of translation studies. Few linguists would deny that a translator's major problem is to find equivalent elements and that the primary task of a translation theorist is to define the nature and conditions of translation equivalence (Catford 1965: 21; cf. also Bao Z.N. 1983: 63).

Translators, translation theorists, linguists, semanticists and language philosophers are constantly attempting to overcome this problem. Although most of them acknowledge the existence of equivalence between languages there are a few who deny it. But the fundamental divergence of opinion is not concerned with the existence of equivalence in intra-lingual and inter-lingual translations; the dispute is generally focused on the extent to which the comparable elements of two languages can be said to be equivalent. At what level? In which aspects? These are discriminating questions to which answers of varying degrees of adequacy can be found in the literature of translation studies, linguistics, semantics and language philosophy.

The general opinion is that an equivalent is a word or phrase that in a specific context exactly corresponds to the smallest unit in the original (Soukalienko 1981: 188). Obviously, this is a vague and ambiguous definition which raises two immediate questions. Is "the smallest unit" a phoneme, sememe, morpheme, word or phrase? What is the precise meaning of "exactly corresponds to": does it imply full equivalence? Linguistic facts prove that no full equivalence can ever be established between two languages. Even synonymy in the same language, as Jacobson (see Bassnett-McGuire 1980: 14-15) illustrates, does not yield equivalence 1 . For example, with "murder" and "kill deliberately" Dillon (1977: 10-11) believes that the phrase is equivalent to the word, for "all of the components of one sentence are present in the other and no others:
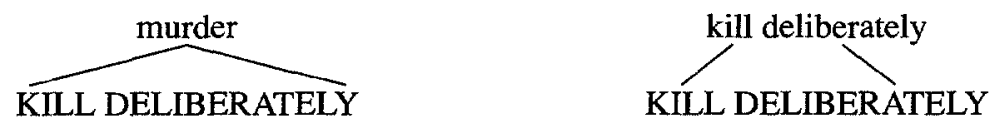

Figure 1

This linguistic equation is challenged on the ground that language is not mathematics. Although "murder" contains the semantic elements "KILL" and "DELIBERATELY," it is more than the sum of the two elements combined. The diagram on the left is not an adequate semantic description of the word "murder" as an important element has been omitted. There is a malevolent element in the word "murder" which in some contexts is absent from the phrase "kill deliberately." One can kill invaders 
deliberately and justifiably, but murder is a universal violation of human societies. One can kill an animal deliberately but this is not regarded as murder except in a world of fantasy. In short, there are some elements in the word "murder" which cannot be "translated" into the phrase "kill deliberately." Since full intra-lingual equivalence cannot be achieved, full inter-lingual equivalence is even less attainable. When the impossibility of full equivalence has been acknowledged, it is then necessary to ask to what extent translation equivalence can be set up? According to Augustine (see Kelly 1979: 24), if a sonus or vox in the target language can be "traced to the same significatio or to one which shared a significant number of characteristics," there is translation equivalence between them ${ }^{2}$. This principle of equivalence is based upon extratextual references. Though useful in many cases, it is inadequate because it entirely ignores the linguistic significance of language. Also, the same significatio may be found missing in the other society due to cultural differences.

Approaching the problem from a communicative point of view, Catford (1965: 49; c.f. Bao Z.N. 1983: 68-69; Wang Z.L. 1983: 5) takes situational features into account. He believes that items from two languages "rarely have 'the same meaning' in the linguistic sense; but they can function in the same situation." Items that are interchangeable in a given situation are therefore translation equivalents and the words selected in a TL code system are not those synonymous to the SL items, but those "with the greatest possible overlap of situational range." For example, "Yóuqī wèigān" should not be translated as "The paint is not dry," but as "Wet paint" (Wang Z.L. 1983: 5). This standard of translation equivalence places emphasis on the effect of communication. Translation equivalence is set up if the purpose of communication has been fulfilled. A word or expression from the target language that is considered appropriate to the same speech situation can be a substitute for the corresponding element in the source language. A Chinese stylist (Wang Z.L. 1983: 60-61) expands this theory, claiming that truly equivalent lexical items should have similar emotional impact: whether they are original or hackneyed, harmonious or discordant.

With communicative, stylistic or literary effects in view, these theorists lay stress on la parole. They are striving to establish equivalence on the plane of syntagma ${ }^{3}$. Although they acknowledge that there is no full equivalence, owing to linguistic and cultural disparities, they do not doubt the possibility of equivalent effect when certain requirements are satisfactorily fulfilled. Equivalence in their view is merely something that serves parallel purposes or functions in a similar way in a specific situation. However, la parole is only part of language; it is language in use. This presupposes $l a$ langue, for without a system of linguistic codes there would be no employment of it in social contact, hence no speech nor any communication. If this aspect of la langue is not taken into consideration when trying to define the nature of equivalence, any conclusions that are drawn are inevitably defective due to an unbalanced view of language.

Translation is not a process in which function substitutes function or purpose substitutes purpose; function and purpose are merely performed by the linguistic codes concerned. When a code-unit from another linguistic system is chosen, what is first contacted is not the same function or purpose, but a physical aspect which is entirely new yet similar in some aspects.

Newmark (1981: 27) attempts a wider interpretation of the problem. In his opinion, equivalence is set up not merely in meaning, but in structure or usage. Aware of the dichotomy of la parole and la langue, he takes into account both the paradigmatic and syntagmatic aspects of linguistic codes. Although he has not dealt fully with this problem 
as yet, he has chosen a viable approach, and further investigation in this direction could result in a valid conclusion.

To say that there is no full equivalence means that equivalence cannot be set up in terms of both the paradigmatic and syntagmatic aspects of linguistic codes to a full extent. It is in this sense that many linguists believe that no two linguistic code-units, intra-lingual or inter-lingual, are equivalent. The relationship between the two aspects of language should be seen, from the angle of translation, as both complementary and contradictory. In the complementary relationship, paradigm and syntagma combine to function and without either of them communication would be found to fail. Lacking paradigm, language would be a jumble of senseless signs; these signs only gain expressive capacity by forming a paradigmatic relationship to other signs within the linguistic system, or by being arranged, together with other signs, into a particular structure. Lacking syntagma, the expressive capacity of language would be reduced to a minimum, for isolated words do not and cannot mean very much. When words are arranged in a certain order which conforms to the appropriate grammar, their expressive capacity escalates. Every day millions of books are published, the majority of which are not dictionaries yet they contain greater meaning than dictionaries. The reason for this increased meaning is the web of paradigm and syntagma which has been woven into each of them. In other words, to mean or express is to make use of or explore the linguistic system on the one hand and the specific context on the other. Meaning grows out of structure and sequence.

The contradictory relationship between the paradigm and syntagma of one language and those of another, places the translator in a dilemma for his task is to mean and express ideas which have already been meant and expressed; no two code-units, either intra-lingual or inter-lingual, occupy exactly the same paradigmatic and syntagmatic status. This phenomenon accounts for the fact that dictionary equivalents often do not fit precisely into a specific context and any expression in a given context does not necessarily have a counterpart available in a bilingual dictionary. Striving to an extreme extent for equivalence on the paradigmatic plane frequently results in an unintelligible TL version, while striving for equivalence to the same degree on the syntagmatic plane seldom fails to distance the TL version intolerably from the original. As the aim of a translator is to communicate, the production of an unintelligible version defeats the object of translation. On the other hand, translating is not creative but an act of re-creation, using that which has already been created in a different linguistic code system. The translator who distances the $\mathrm{TL}$ version from the original by expressing himself rather than the original source has failed to define the distinctions between writing and translating. The translator and the translation theorist are trapped between these two opposing forces and they must necessarily establish equivalence at the most appropriate point between the two. A compromise is inevitable.

\section{TYPES OF EQUIVALENCE}

Equivalence to a full extent on both the paradigmatic and syntagmatic planes is evidently an impractical ideal. In translation, equivalence can be established only on the syntagmatic plane while simultaneously giving consideration to the demands of paradigm. This situation has given rise to various types of equivalence, which are well developed among linguists of the twentieth century. Neubert propounds a theory of texts, considering translation equivalence as a semiotic category that contains "a syntactic, semantic and pragmatic component." He argues that:

These components are arranged in a hierarchical relationship, where semantic equivalence takes priority over syntactic equivalence, and pragmatic equivalence conditions and modifies 
both the other elements. Equivalence overall results from the relation between sings themselves, the relationship between signs and what they stand for, and the relationship between sings, what they stand for and those who use them. (see Bassnett-McGuire 1980: 27).

In his treatment of the problem Popovič takes stylistic aspect into account. His approach may be helpful in translating idioms, where the difficulty of determining stylistic appropriateness often confronts translators. He distinguishes four types:

(1) Linguistic equivalence, where there is homogeneity on the linguistic level of both SL and TL texts, i.e. word for word translation.

(2) Paradigmatic equivalence, where there is equivalence of "the elements of a paradigmatic expressive axis," i.e. elements of grammar, which Popovic sees as being a higher category than lexical equivalence.

(3) Stylistic (translational) equivalence, where there is "functional equivalence of elements in both original and translation aiming at an expressive identity with an invariant of identical meaning."

(4) Textual (syntagmatic) equivalence, where there is equivalence of the syntagmatic structuring of a text, i.e. equivalence of form and shape. (Bassnett-McGuire 1980: 25)

The simpler - and more popular - method of dealing with the problem is the dichotomous distinction: formal equivalence (correspondence) versus dynamic (textual) equivalence. Catford (1965: 27; cf. Bao Z.N. 1983: 64-65) takes this approach. For him, textual equivalence is established on the basis of performing a similar function in a specific speech situation (or context), whereas formal correspondence depends on the compatibility between the linguistic categories from two languages. Catford acknowledges that formal correspondence can usually be obtained only at the expense of the intelligibility of the TL version, which in consequence breaks down communication; he suggests that in the process of translation formal correspondence is adjusted in various ways to guarantee the translation equivalence. Such adjustments of formal correspondence are called translation shifts, which he defines as "departures from formal correspondence in the process of going from the SL to the TL" (1965: 73). Catford defines two kinds of shift: (1) level-shifts: "a SL item at one linguistic level has a TL translation equivalent at a different level" (1965: 73), and (2) category-shifts: "departures from formal correspondence in translation." The category-shifts are subdivided into structure-shifts, class-shifts, unit-shifts and intra-system-shifts (1965: 76).

Like Catford, Nida (1964: 159; Nida and Taber 1969b: 24; Jin and Nida 1984: 85) also distinguishes two types of equivalence: formal and dynamic. But his description of the nature of these equivalence types is quite different from Catford's. In Nida's definition, formal equivalence is no longer confined to linguistic categories; in fact, it has no apparent connection to linguistic categories and it "focuses attention on the message itself, in both form and content." He adds, "in such a translation one is concerned with such correspondences as poetry to poetry, sentence to sentence and concept to concept." Nida describes this as "a gloss translation" for it demands that the TL audience must equal the SL audience in an understanding of the SL context. Dynamic equivalence is dependent on the principle of equivalent effect, that is, "the relationship between receptor and message should be substantially the same as that which existed between the original receptors and the message."

Despite the divergence and apparent disparity in terminology, classification, and viewpoint, there is a fundamental presupposition underlying these ideas: the problem of equivalence could and should be dealt with on the paradigmatic and syntagmatic planes, since full intra-lingual and inter-lingual equivalence is a rare contingency. All the efforts 
devoted to this problem so far might well be subsumed under the dichotomy: formal equivalence and dynamic equivalence. These are the well-developed types of equivalence discussed in twentieth-century literature of translation studies. Formal equivalence, to quote Louis Kelly (1979: 24), "is correspondence between linguistic units independent of any idea of content"; dynamic equivalence is "characterized by Nida as "the closest natural equivalent to the source-language message'4." The contrast between formal and dynamic equivalence is clearly illustrated by Beekman (cited in Kelly 1979: 24) in a remarkable table presented below:

\begin{tabular}{|c|c|c|c|}
\hline \multirow{2}{*}{ Types of Correspondence } & \multicolumn{2}{|c|}{ Illustration of Types } & \multirow{2}{*}{ Meaning } \\
\hline & Source Language & Receptor Language & \\
\hline $\begin{array}{l}\text { (1) correspondence of } \\
\text { form and function }\end{array}$ & $\begin{array}{l}\text { form } \\
\text { function }\end{array}$ & $\longrightarrow$ function & correct \\
\hline $\begin{array}{l}\text { (2) correspondence of } \\
\text { form but not of } \\
\text { function }\end{array}$ & $\begin{array}{l}\text { form } \\
\text { function }\end{array}$ & $\begin{array}{r}\text { form } \\
\text { function }\end{array}$ & $\begin{array}{l}\text { wrong or at best } \\
\text { obscure }\end{array}$ \\
\hline $\begin{array}{l}\text { (3) correspondence of } \\
\text { fonction but not form }\end{array}$ & $\begin{array}{l}\text { form } \\
\text { function }\end{array}$ & $\begin{array}{r}\text { form } \\
\text { function }\end{array}$ & $\begin{array}{l}\text { correct if form } \\
\text { irrelevant }\end{array}$ \\
\hline $\begin{array}{l}\text { (4) no correspondence of } \\
\text { either form or function }\end{array}$ & $\begin{array}{l}\text { form } \\
\text { function }\end{array}$ & $\begin{array}{r}\text { form } \\
\text { function }\end{array}$ & zero \\
\hline
\end{tabular}

Figure 2

Type 1 , called full equivalence, is where coincidence occurs simultaneously on both the paradigmatic and syntagmatic planes. This is the ideal and also the type least found. Type 4 , being non-correspondent by nature, would not occur in any normal translation unless the translator deliberately sets out to meet certain purposes or requirements such as deliberate distortion for political reasons. Type 1, being an ideal, is not a practical goal, and type 4 is a non-achievable goal, so these remain on the periphery of the discussion; type 2 and type 3 receive much more theoretical attention, and appear to be in sharp contrast. In the process of translating, they usually provide either-or alternatives between which the translator must make a choice on the basis of his view of translation.

\section{DYNAMIC EQUIVALENCE}

To this point various types of equivalence have been discussed briefly. My aim now is to assess Nida's theory of dynamic equivalence but I am convinced that it cannot be justly evaluated unless placed in its historical context. Influential as Nida's concept is, it is only one of the many plausible ideas on the subject, and, compared to the other theories, its merits and defects reveal themselves more clearly. Seen in isolation, it could create an erroneous impression as the only established idea on the subject, as if it developed to its present stage in a historical vacuum. An overall review of literature 
relevant to the issue will provide a background for an attempted assessment of Nida's dynamic equivalence theory. This section, although concentrating on an analysis of Nida's dynamic equivalence theory, will include some comparisons of Nida's ideas with those of other linguists.

Although distinguishing formal and dynamic equivalence, Nida perceives them in such complete contrast that one denies the other. They do not stand as two aspects of the problem, like those of Catford's. With translation equivalence dependent on situational function, Catford recognizes the relation between formal correspondence and textual equivalence. In spite of his conviction that the SL and TL items rarely have the same meaning in the linguistic sense (1965: 49), he does not ignore the formal aspect of language but expends much thought in this area. His theory of translation shifts is intended to explore the relation between the two types of equivalence, and it is comprehensively demonstrated by him in a carefully calculated procedure. By contrast, Nida never relates his types of equivalence to each other in such a way. In fact, Nida's types each represent a different way of translating: one aims at transferring the message in both form and content while the other endeavours to achieve equivalent effect. Nida rejects the former as "gloss translation," and elaborates on the latter, which becomes the cornerstone of his translation theory. Since he believes that "anything that can be said in one language can also be said in another" (Dil 1975: xiii), it is obvious that he does not reject the "gloss translation" on account of message content but on account of message form. His dynamic equivalence heavily stresses the parallel relationships between, on the one hand, the TL audience and the message equivalent, and on the other hand, the original audience and the original message. Little thought is given to the SL form. This is evidenced by his definition of dynamic-equivalent translation (1964: 166):

dynamic-equivalent translation is "the closest natural equivalent to the source-language message," directed primarily toward equivalence of response rather than equivalence of form.

Nida's view of language influences his approach to the problem of equivalence. For him, language is a functional tool of communication and, for efficient communication, linguistic utterances must be receptor-oriented. This principle is true not only of intralingual but also of inter-lingual communication. Consequently, he believes that translation equivalence can be set up only if a translation fulfils the conditions of "the closest natural equivalent" to the source language text (Wilss 1982: 148).

Nida's approach to the problem of equivalence also presupposes the separability of content and form. The idea that linguistic form and content are separable is out of date. Kelly (1979: 56) says that, in translation, language form has long been regarded as merely the instrument used to convey meaning. He considers that it has always been customary for translators to adapt the target language to fit the content of the source language. With such a view of language, Nida (1964: 156) naturally considers form as "nothing apart from content," since he views it metaphorically as a vehicle for content or the clothing 5 in which the content is dressed. Because there can be no identical equivalents and no identity in detail, Nida strives for the total impact of a translation close to the original; he aims at an ambitious goal which is extremely intangible.

Nida's attitude toward linguistic content and form has been criticized by Meschonnic (cited in Kelly 1979: 126), who argues

La «langue» - la «littérature», ou la langue - la culture, ou le sens - la forme : il n'y a pas deux choses dissociables, hétérogènes. Quand il y a un texte, il y a un tout traduisible comme tout. 
Walter Benjamin shares Meschonnic's point of view. They give equal importance to both form and content, for, if the target text is to reflect the source truly, both form and content must be reproduced (Kelly 1979: 126).

Many linguists, including those already mentioned, respect form to a greater or lesser degree. It has been noted that Catford has paid much attention to the linguistic form in his effort to solve the problem of equivalence. Neubert's definition contains "a syntactic component" and Popovic has also taken formal elements into account when describing equivalence types. In his book Approaches to Translation, Peter Newmark (1981: 145) has put a strong stress on form:

Whilst semantic equivalence is the only basic principle of translation, it can only exist if there is the maximun equivalence of form and frequency in usage.

He maintains that the formal elements of a well-written text must be significantly important, and that the translator should respect them, endeavouring to represent them in the target text (1981: 127). Concerning a translation approach, he appears to have taken a stand opposite to Nida's; he advocates semantic translation wherever possible whereas Nida defies the concept of literal translation 6 .

In Nida's approach to the solution of equivalence issues, equivalent response outweighs all other factors, for he (1964: 159) even claims that in a dynamic equivalence translation "one is not so concerned with matching the receptor-language message with the source-language message, but with the dynamic relationship...," that is, the equivalent response. The dynamic equivalence is thus based on the "double relationship" (Jin and Nida 1984: 85) 7 . It is not surprising to find him quoting as an example of dynamic equivalence translation, J.B. Phillips' rendering of Romans 16:16, where the Greek $\vartheta \imath \lambda \eta \mu \alpha$ (kiss) becomes a "hearty handshake." This example Bassnett-McGuire (1980:26) regards as "a piece of inadequate translation in poor taste" which reveals "the weakness of Nida's loosely defined equivalence types." Kelly $(1979: 132)$ is also critical about it, saying: with kiss rendered as "hearty handshake", "the liturgical symbol of the non-sexual kiss has been missed, because the non-comformists have not preserved the liturgical structure in which it had meaning."

Another defect of Nida's description of dynamic equivalence is also noticed by Bassnett-McGuire (1980: 26): "Nida's categories can actually be in conflict with each other." To support her argument, she states that "E.V. Rieu's deliberate decision to translate Homer into English prose because the significance of the epic form in Ancient Greece could be considered equivalent to the significance of prose in modern Europe, is a case of dynamic equivalence applied to the formal properties of a text." Clearly, the idea of dynamic equivalence becomes involved "in areas of speculation and at times can lead to very dubious conclusions." The root of this confusion lies in two facts; first, no apparent consideration is given to form in his definition of dynamic equivalence; second, his types of equivalence representing two opposing methods of translating do not operate within the same framework, like those of others, in a dialectical way of contradiction and complementation.

Nida has displayed excessive zeal in emphasizing equivalent response. It is generally accepted that translation is a form of communication in which the receptor is a very important element demanding consideration. But an act of communication cannot be well accomplished with attention focused solely on the receptor. The probable response from the receptor can of course be a factor conditioning the sender's effort, but the message should also be interpreted by the receptor as what is intended by its source. Besides, the message itself - together with its medium - plays an equally important role in the act of communication. In a particular situation, one factor may take priority 
over the other two but neglect of any of the three to an immoderate degree is not recommended. Translation is communication only in a special sense; in normal communication people convey their own ideas, but the translator at work is conveying the original writer's ideas. There is a narrow boundary line between creative writing and translation and if the translator fails to keep sight of the source and its message he could easily trespass on the creative writer's domain.

In contrast to Nida, Matthew Arnold (quoted by Bassnett-McGuire 1980: 69) advises the translator not to trust the reader, nor to rely on his own evaluation of the rendering, but to consult bilingual connoisseurs concerning its effect on them. $\mathrm{He}$ proposes that "the translator must focus on the SL text primarily, and must serve that text with complete commitment. The TL reader must be brought to the SL text through the means of the translation." Extension of this theory leads to the extreme proposition that a translator must serve the original text as a slave serves a master. This attitude could prove to be a source of pessimism for translators. If Nida's approach is used to counterbalance such a restrictive practice, its merits will be revealed. In the "Introduction" to Language Structure and Translation: Essays by Eugene A. Nida, Anwar S. Dil (1975: xiii) says of Nida:

He has made notable contribution in recent years to the creation of a climate of more openminded acceptance of the fact of cultural diversity among the peoples of the world, as a first step toward better human communication and understanding. Underlying this approach is Nida's deep conviction...that anything that can be said in one language can be said in another with reasonable accuracy by establishing equivalent points of reference in the receptor's culture and matching his cognitive framework by restructuring the constitutive elements of the message.

Nida's theory of dynamic equivalence has undoubtedly encouraged greater confidence in the possibility of inter-lingual communication. Due to this he is regarded as one of the most prominent figures in twentieth century translation studies.

\section{EQUIVALENT RESPONSE}

"Equivalent effect" was apparently coined by P. Cauer in 1896 (cf. Newmark 1981: 132). It is a new term though it is not entirely a new idea; in fact, it is a remarkable development of the much older term fidelity. Formed almost 200 years earlier, John Dryden's opinion was that a good rendering should show its readers what the original text would have been like if it had been written in their vernacular (see Steiner 1975: 256). Regarding his own practice, he (quoted by Bassnett-McGuire 1980: 60) observes: "I have endeavoured to make Virgil speak such English as he would himself have spoken, if he had been born in England, and in this present age." In his eyes, a translator is like a portrait painter; therefore he maintains that the translator should be required to make his rendering bear close resemblance to the original. Although still author and SL text oriented, Dryden already had in his mind a vague aim of achieving effect similar to that of the original, which is the first step moving away from fidelity or faithfulness towards equivalent response.

Dryden's metaphor is adopted and extended by Tytler, who differentiates between them, stating that the translator, unlike the painter, who uses different "colours," should still paint "a picture" possessing force and effect similar to that of the original (ibid.: 63). Norton (quoted in Amos 1973: 124) repeats this theme: "to say that in English which I conceived to be his [the author's] meaning" in the source language.

Matthew Arnold (cited in Savory 1957: 45; see also Nida 1964: 164) continues this line of thought, declaring that "a translation should affect us in the same way as the original may be supposed to have affected its first hearers." For Arnold, to obtain the 
similar or equivalent effect becomes a conscious purpose and effort, but his concept of the reader is somewhat different from that of later translation theorists. His "us" in some cases actually refers to the bilingual connoisseurs (cf. Savory 1975: 66; Fan C.Z. 1978: 95). A similar idea of the reader is held by Schleiermacher (see Bassnett-McGuire 1980: 71), who maintains that the TL reader should "become the equal of the better reader of the original." Obviously, theirs are the chosen ones among readers. However, Tytler (cf. Luo S.S. 1983: 14) sees the reader as a native speaker of the target language. Although regarding the effect of a translation Tytler makes a proposition similar to Arnold's 8 , he aims at "equivalent effect" in a broader or truer sense, and this leads directly to Nida's equivalent response.

According to Nida (1964: 148-149), equivalent response occurs when the TL receptors respond to a translation in substantially the same manner as the SL receptors respond to the original. In other words, the translator is not concerned with the formal matching of the TL message with the SL message, but "with the dynamic relationship of the various receptors to the respective message." Equivalent response rests on dynamic equivalence; expressed alternatively, dynamic equivalence is set up to elicit equivalent response. This is one criterion in assessing translations, so it is an integral part of Nida's theory.

A brief glance at the history of translation theory presents a clear picture of the recognizable development of equivalent response from its initial source - fidelity. Indeed, equivalent response is only a new angle from which this immemorial and insoluble problem can be viewed. The ultimate aim of fidelity and equivalent response is to define the nature of translation, to devise a set of principles or norms to guide the act of translating, and to work out a criterion by which translations can be rationally assessed. The theories are progressively linked and their development is marked by the change in emphasis on different aspects of the subject. Fidelity is strictly author/SL text oriented, and this is clearly shown in J.P. Postgate's (quoted in Chao 1976: 168) statement:

the prime merit of translation proper is Faithfulness, and he is the best translator whose work is nearest to his original.

A similar attitude to fidelity in translation is revealed by $Q$. Hoare and $G$. Nowell Smith 9 . Equivalent effect places more conscious attention on the receptor, although translation is still author/SL text centered, as in the case of Tytler. With Nida's equivalent response the centre of stress moves to the TL receptor, and is less concerned than its predecessors with the source message.

Nida's concept of readership is no longer a shallow abstract generalization, but a much more concrete idea. He classifies TL readers into several types according to factors such as age, sex and the level of education received. In order to communicate efficiently, the source should "sense in advance how an audience is likely to react to what is said" (Nida and Reyburn 1981: 24). In accordance with this viewpoint, he advocates that different translations of the same SL text should be produced to cater for different types of readers in the hope that equivalent response will be aroused to the highest degree. This appears more plausible than Tytler's assumption that TL readers are equally endowed with decoding ability.

Attitudes to readers can also be traced well back into the history of translation theory. For example, Aelfric always has a clear idea of the nature of his readers and takes great care to make his rendering attractive to them (cf. Amos 1973: 5). Similarly William Caxton and other early translators all desire to be understood by their readers including 
the unlearned (ibid.: 18, 38-40). But they do not "recognize any compelling necessity for faithfulness" (ibid.: 45). Possibly their aim in translating is primarily to be articulate.

In The Art of Translation, Savory (1957: 57-58) distinguishes four types of TL readers: (1) those who do not know a language other than their mother tongue, (2) foreign language students, (3) those who used to know the source language and (4) scholars who are proficient in the foreign language. With different types of readers in view, the translator has to invest each rendering with an expected function of its own. The rendering can adequately fulfil this function provided it is received by the particular types of readers for whom it has been specially designed. This concept of reader-analysis is inherently congenial to Nida's communicative approach to translation and its influence on Nida is evident.

A general conclusion can be drawn from the foregoing outline. Nida, having inherited the traditional concept of TL readers, fits it into his theoretical framework as a component part. On the other hand, equivalent response is a radical development of the traditional ideas concerning the nature and quality of translation; it is so radical that it is almost contrary to its forerunners.

For Nida, equivalent response is the best criterion for judging the quality of a translation; it is also a goal which a translator is expected to attain. To elicit equivalent response, according to Nida, the translator should produce a dynamic-equivalent text that is understandable to the TL reader, that is to say, he should produce a text in the target language which is capable of evoking an understanding equivalent to that which the original was intended to elicit. He must employ "anticipatory feedback" to direct the message to the TL readers so that they will know how the SL readers must have understood the message (Nida and Reyburn 1981: 24; cf. also Grace 1982: 17). The principal standard in such translation is the presumed possible feedback from the type of receptors for whom the rendering is intended. Again, Nida rests his theory on an incalculable basis. In reality, feedback occurs only after the receptors have reacted to a particular rendering. To anticipate possible feedback from a certain group of receptors before a specific translation is even published must necessarily amount to guesswork. This approach involves translators in speculation and individual translators may anticipate it each in his own way, for they may not share the same classification of TL audience. In addition, a translator's personality, education, world-view, - and all the other elements which create an individual - must influence the speculation; the hypothetical feedback will vary with each speculator. If translators do not watch the SL text carefully, their individual products could appear to have emerged from entirely different SL texts.

Consequently, doubts have been cast upon equivalent response. Is it possible to produce a TL rendering whose relationship to its audience is truly parallel to that between the SL text and the SL audience? The same basic doubt is expressed in the question: can equivalent response be achieved by a work composed of a different language? If this is possible, what supports the TL relation? Presumably it would be claimed that dynamic equivalence and/or the closest natural equivalence do so, but if this explanation is accepted then a vicious circle has been created. The "anticipatory feedback" serves as a guiding principle in the process of translating, orienting the message to the particular $\mathrm{TL}$ audience. Based on this speculated response, dynamic equivalence and/or the closest natural equivalence are searched for and then determined. Dynamic equivalence and/or the closest natural equivalence are expected in turn to solicit the anticipated feedback, namely, equivalent response. 
Notes

1. W.V.O. Quine holds the same view, see S.D. Ross (1981: 10).

2. Cf. H. Stephen Straight (1981: 44) who thinks that "referential equivalence cannot hope to be an adequate criterion for the handling of idiomatic or metaphoric expression."

3. By "syntagma," I mean any particular context, which can be a word, a sentence, a paragraph or even a whole article. By "paradigm," I mean the status and associations that any linguistic code-unit may occupy or share in the linguistic code system. I believe that any linguistic code or code-unit functions on the basis of its status and associations in both the linguistic system (la langue) and a specific context (la parole). A unit in a particular context finds its status in that context and relates itself to its neighbouring units. However, this does not mean that it has lost its status and associations in the linguistic code system. It only has its code-system status and associations constrained or modified in the context. The checks and balances between la langue and la parole, their reciprocal influence and impact have multiplied the expressive capacity of language, allowing sensitivity in meaning. The terms "syntagmatic plane" and "paradigmatic plane" are also used in this sense.

4. These are generalizations made by Kelly defining formal and dynamic equivalence found in the literature of modem translation studies. They should not be confused with Nida's definitions.

5. Cf. Dryden who compares form to dress: "...it's time to look into ourselves, to conform our genius to his, to give his thought either the same turn, if our tongue will bear it, or if not, to vary but the dress, not to alter or destroy the substance" (quoted in Amos 1973: 158).

6. Newmark distinguishes two methods of translation: semantic and communicative. Semantic translation, which he declares to be different from literal translation (1981: 63), is author/SL text oriented, and therefore a concept similar to literal translation. Communicative translation, which is intended to produce the same effect on the TL readers as was produced by the original on the SL readers (1981:22), is receptor oriented, like dynamic equivalence translation.

7. By "double relationship," Nida refers to the relationship of TL receptors to the TL text and that between the original receptors and the original text. He claims that this double relationship - equivalent response "provides the basis for the dynamic equivalence" (Jin and Nida 1984: 85).

8. Cf. Bassnett-McGuire (1980: 47): Tyndale stated that the intention of translating was to provide a rendering as clear as possible for the layman. Cf. also Yang Z.H. (1984: 292); Kelly (1979: 209).

9. O. Hoare and G. Nowell Smith declared that they preferred fidelity to good English, see Newmark (1981: 40). 